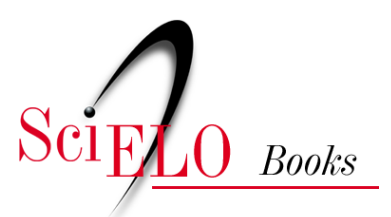

\title{
Reflexões \\ Empresta a senha do wifi?
}

\author{
Nelson De Luca Pretto
}

PRETTO, N.D.L. Empresta a senha do wifi? In: Educações, culturas e hackers: escritos e reflexões [online]. Salvador: EDUFBA, 2017, pp. 97-98. ISBN: 978-85-232-2019-8.

https://doi.org/10.7476/9788523220198.0010.

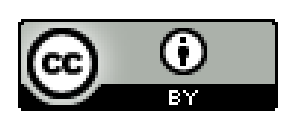

All the contents of this work, except where otherwise noted, is licensed under a Creative Commons Attribution $\underline{4.0 \text { International license. }}$

Todo o conteúdo deste trabalho, exceto quando houver ressalva, é publicado sob a licença Creative Commons Atribição 4.0.

Todo el contenido de esta obra, excepto donde se indique lo contrario, está bajo licencia de la licencia Creative Commons Reconocimento 4.0. 


\section{Empresta a senha do wifi?}

Não temos... Não dou, não! Essas, seguramente, serão as respostas que mais ouviremos se as operadoras de telecomunicações continuarem insistindo na ideia de limitar o chamado consumo de dados na internet.

Para melhor entender a questão, é preciso voltar um pouco no tempo. No final dos anos de 1980, Tim Bernes-Lee, Vinton Cerf e tantos outros criaram os protocolos computacionais que viabilizaram a existência do que hoje é conhecido como internet. $\mathrm{O}$ que eles queriam era disponibilizar suas invenções sem nenhum tipo de trava - tecnológica ou legal. Eles tinham um desejo de contribuir para o avanço da ciência, desenvolvendo soluções tecnológicas para a humanidade. Por essa razão, não patentearam esses protocolos. Se esse começo tivesse sido diferente, nada seria igual ao que temos hoje. Em 1995, num esforço conjunto de diversos órgãos públicos e instituições, começamos no Brasil, e na Bahia também, a implantação da internet comercial. Passamos a viver a era da conexão generalizada, mesmo sabendo que há ainda muito a ser feito para que, efetivamente, todos estejam plenamente conectados à rede.

$\mathrm{Na}$ prática, a maneira de se ver vídeos e filmes, comunicar, estudar, escrever, namorar, foi profundamente transformada com a internet.

Desde muito, as operadoras não param de ameaçar o funcionamento da rede com medidas restritivas, tentando implantar uma legislação que se adapte aos seus modelos de negócios. Foi assim com a batalha para a definição de um Marco Civil da Internet, uma espécie de Constituição da rede, e que, após aquele longo e democrático processo, serviu de exemplo para o mundo.

Mas as operadoras insistem em modificá-lo. A última cartada, iniciada pela Vivo, foi o anúncio do corte da conexão fixa, aquela que contratamos em casa, no comércio, indústria, sindicatos e associações, após atingirmos o chamado limite de uso de dados. Na prática, isso significa que a internet poderá "acabar" em um ou dois dias, para quem usa a rede para ver filmes e vídeos, bater papo publicar conteúdos, por exemplo. 
A Anatel, voltando atrás do que o seu presidente havia declarado irresponsavelmente, proibiu a implantação dessa prática temporariamente, enquanto não há um avanço no debate sobre a regulamentação do assunto. E isso só aconteceu porque os ativistas da cultura digital, os militantes da defesa do consumidor, a $\mathrm{OAB}$ e tantos mais, protestaram imediatamente e de forma contundente contra o inevitável "fim da internet ilimitada", nas palavras do presidente da Anatel.

A implantação desse tipo de limitação gerará, no cotidiano, um uso egoísta e individualista da rede, contrário a tudo que temos preconizados ao longo dos últimos anos e que é da própria natureza da internet.

Queremos a nossa internet de volta, toda nossa, com pleno uso para que possamos, com ela, nos organizar enquanto movimentos sociais, produzir e postar conteúdos, intensificar os usos coletivos e solidários das redes e da infraestrutura de telecomunicações.

Precisamos, sim, de políticas públicas que garantam tudo isso, pois não podemos deixar que os avanços científicos e tecnológicos sejam apropriados pelas grandes corporações multinacionais, em detrimento das liberdades e da democracia.

\section{O aplicativo do Axé}

Um dia desses, visitava Mãe Stella de Oxóssi, 90, no terreiro Ylê Axé Ôpô Afonjá e, nem bem cheguei, ela me recebe com uma pergunta à queima roupa: - Professor, e esse negócio de aplicativos, o que é mesmo isso?

Confesso que fiquei surpreso com a pergunta. Surpreso de bobo, pois, desde sempre que conversamos percebo a vitalidade e a vibração em 